\title{
Oscillation between Modernism to Postmodernism in Shakespeare's Hamlet
}

\author{
Noorbakhsh Hooti \\ English Department, Faculty of Arts, Razi University, Kermanshah, Iran \\ Email: nhooti@yahoo.com
}

\begin{abstract}
The universality and uniqueness of Shakespeare is his unyielding and resisting insistence on not surrendering to the fossilized logos and metanarratives. He has remained a genius, whose resisting and challenging views have surpassed time and place. This paper makes an attempt to show the dominant traits of modernism and postmodernism in Hamlet. The focal point of the study is to unfold the shift of modern and postmodern traits of the characters and as well as their oscillation between modern and postmodern world. By spotlighting Shakespeare's modern and postmodern notions in his Hamlet, the study wants to put on show the affinity of Shakespeare with the $2^{\text {th }}$ and 21 th century generations, who vacillate between modern and postmodern world.
\end{abstract}

Index Terms—-modernism, postmodernism, oscillation, logos, metanarratives

\section{INTRODUCTION}

Different researchers have worked on Shakespeare's tragedies, especially his well-appreciated Hamlet. The main focus of this paper is to analyze the selected situations of the leading characters namely Hamlet, Claudius and Gertrude in Hamlet in both modern and postmodern bedrocks. Before reaching this analysis, the researcher gives a brief introduction of Modernism and Postmodernism.

\section{MODERNISM}

Literary modernism is a twentieth-century movement which takes new aspects of literature, as concerned with the changing situation of the society, into account. The exact period in which the movement appeared is much debated by critics. Brooker argues that some critics extend the period form 1880 to 1950, while some others divide the period and "give priority to the prewar years," or" post-war years". (1972, p.4) Some other critics believe that the movement started in 1890 and finished in 1945 when the Second World War was over. The debate over the beginning or end of modernism is not as significant as its literary ideology which is to be discussed in this research.

Modernism as a "creative violence" (levenson, 2002, p.2) deviates from the literary tradition and turns the holistic and taken-for- granted literary concepts into new internal and mental trends. The significant point to be made here is that "modernist" must be distinguished from "modern". Modern can denote anything done or produced at the contemporary period while modernist refers to specific experimental elements which flout the conventional literary forms. In modern writings, the historical period is emphatically implied, whereas modernist writings lay stress on the dominant techniques and approaches which are deemed to be the touchstones for putting pen to paper.

In the A Dictionary of Literary Terms by Cuddon the definition of modernism has been put forward as follows:

A very comprehensive term applied to international tendencies and movements in all the creative arts since the latter end of the $19^{\text {th }}$ c. Professor Kermode has made a distinction between Palaeo-modernism and Neo-modernism. Paleomodernism refers to early manifestations of new movements concluding, perhaps, c. 1914- 20, while neo-modernism refers to movements (like surrealism [q.v]) since that time. As far as literature is concerned modernism reveals a breaking away from established rules, traditions and conventions, fresh ways of looking at man's position and function in the universe and many ( in some cases remarkable) experiments in form and style. (1977, p. 399).

The above-mentioned citation can be clarifying and revealing as to the hallmarks of the movement. The modernist movement is "a breaking away form established rules" of the previous eras and considers "man's position" and" function" from a view point which is quite bizarre to the eyes of traditionalists. Modernism as " the literature of technology" displays " introversion, technical display, internal self-scepticism " ( Bradbury and McFarlane, 1991, pp. 26-27) to reflect " experiments in form and style" as man's roles and intellectuality change tremendously because of metropolitans and technological developments.

Another issue which instigated the modernist movement was the "nineteenth-century assumptions" which had established themselves as" dead conventions" (Faulkner, 1977, p. 1). Realism and naturalism were some of the touchstones by which the validity of literature was measured. But the modernists who regarded literature as a selfcontained phenomenon reflecting the autonomy of the writer disagreed over the well-established rules of the Victorian 
period and using experimental devices created new literary masterpieces based upon their own reflections and intellectualism.

They believed that "modernization has changed the very nature of reality" and literature "has to change its very nature" (Matz, 2004, p. 6) to dig up the unexcavated monuments of mind.

Modernism which breaks with the past cannot reflect and underpin the flavor of traditional literature. It is revolutionary by nature and creates experimental backgrounds for the disintegration of man's mind and situation to match the modern environment in which consciousness is widely changed. It can mostly be ascribed to the modern era and the peculiarity of contemporary literary analysis. Therefore, it is not historically bound up with any particular period and challenges the conventions. Its aim is paradoxically gained through the literary devices and figures of traditional literature.

\section{A. Epistemological Level}

Epistemology means the study or theory of the nature and grounds of knowledge especially with reference to its limits and validity. According to (Heumer, 2005, p. 27):

common sense, perception, the exercise of the five senses, is the chief means by which we know about the world around us. For this reason, a basic understanding of the nature of perception is important to epistemology. A theory of perception should answer such questions as: What is it to perceive something?, What sorts of things does perception make us aware of?, and How does perception enable us to gain knowledge of the world around us?

The alienation of modern man and his exposure to scientific development and new philosophical theories based on humanism made man wonder what the truth is and how he can achieve knowledge based on his limitations.

McHale talks about the epistemological doubts raised by modernist narratives and the kind of questions emphatically posed through these narratives. He says that:

Modernist fiction deploys strategies which engage and foreground questions such as ...: "How can I interpret this world of which I am a part? And what am in in it?... what is there to be known? Who knows it? How do they know it, and with what degree of certainty? How is knowledge transmitted from one knower to another, and with what degree of reliability? How does the object of knowledge change as it passes from knower to knower? What are the limits of the knowable? And so on. (1983, p. 9)

The significant point to be made about the above-mentioned strategies is that the modernist narratives put these problems forward either directly through questions or they implicitly raise them through the structure of their narratives or other relevant techniques which on the surface seem irrelevant, but in a closer reading unravel their coherence and interconnectedness. The pattern may be implied through the symbols or images prevalent in the story or the underlying structure which points to the epistemological foregrounding of the text at hand.

Taking the epistemological level into account, Matz comes up with the following comments on modernist narrative:

Who is speaking, and how, and why? What aspect of mental life is explored by the writer's choice of narrative levels? And, perhaps most importantly, how is the writer developing a unique mode of narration by combining different levelsby finding some unique way to move up and down the scale that runs from the most inward narration to the most outward? (2004, p.58)

As we can see, Brain McHale and Jesse Matz have differently posed their questions, but the fact is that the essence is the same since the two critics have observed the roles of limitedness and validity in their hypotheses. The only problem we face is that they look at the issue from different perspectives. McHale has taken knowledge into consideration which is the source behind all information and Matz looks at "Narrative" and "narration" as the hallmarks for epistemological foregrounding.

McHale (1983) brings up the following themes as practical in foregrounding the epistemological dimension: "Accessibility and circulation of knowledge, the different structuring imposed on the "same" knowledge by different minds; and the problem of "unknowability" or the limits of knowledge", (p. 9).

These are conveyed through the following devices: The multiplication and juxtaposition of perspectives, the focalization of all the evidence through a single "center of consciousness"... virtuoso variants on interior monologue..., "impeded form "(dislocated chronology, withheld or indirectly- presented information, difficult "mind-style" and so on. (ibid)

The above-mentioned factors are remarkably fruitful in instigating the epistemological level of modernist narratives, but the question which remains is: Does modernism find any answers to the raised questions? The modernist novels are open-ended and inconclusive and do not come up with denouements as we see in realist novels. In other words, they rebel against the established realistic norms; however, they create some alternatives for the problems of uncertainty and doubt through aesthetic forms. They produce "a new realism based strangely on doubt about reality itself" (Matz, 2004, p. 33)

\section{B. Stream-of-consciousness}

In modernist narrative, "loss of order" "led to the belief in its recovery at a deeper level of the mind" (Waugh, 1984, p. 24). They turned from the objective descriptive world of realism to the subjective personal world of the author. In this way, the traditional narrative techniques could not work any more; Modernists turned to "stream of consciousness" as an experimental strategy to delve into the mind of man as the ocean of knowledge. "Now human consciousness and 
especially artistic consciousness could become more intuitive, more poetic; art could now fulfill itself' (Bradbury and McFarlane, 1991, p. 25)

Stream of consciousness is a phrase coined by William James in his book called principles of psychology (1890). Abrams defines it as follows:

Stream of consciousness is the name for a special mode of narration that undertakes to reproduce, without a narrator's intervention, the full spectrum and the continuous flow of a character's mental process, in which sense perceptions mingle with conscious and half-conscious thoughts memories, expectations, feelings, and random associations (1971, p. 202)

The mingling of "sense perceptions" "with conscious and half-conscious" elements of human understanding may seem bizarre at first glance, but at a deeper level, all these metal processes interact to discover the "Epistemological cause" (Bradbury and McFarlane, 1991, p. 25) of human consciousness.

Stream of consciousness as the interpretive strategy of artistic independence can take many forms here what Matz says can be of great help:

Stream of consciousness could take many forms. The main goal- the "unmediated" discourse of the mid itself-could be reached in different ways depending on the state of mind in question or a writer's theory about where to locate the mind's most basic activity stream of consciousness might mean a very random jumble of perceptions and imagings, or it might mean a very direct pursuit of some train of thought, as long as its narration proceeds as if unprocessed by any authorial intervention. (2004, p. 54)

Stream of consciousness includes interior monologue as a subcategory or "interchangeably". Interior monologue is concerned with that species of consciousness which undertakes to present to the reader the course and rhythm of consciousness precisely as it occurs in a character's mind (Abrams, 1971, p. 202)

Interior monologue is widely used in modernist narratives to foreground the epistemological level of characters' limitations (McHale, 1983: 9). This narrative strategy, the perceptions " would still not be wholly coherent, but they wouldn't descend so much into the irrational, the unconscious, or the nonverbal". (Matz, 2004, p. 56). The important point to be made here is that the writer "does not proceed" traditionally" with a view to bringing a continuity of exterior events to a planned conclusion" (Faulkner, 1977, p. 16). In this way, the traditional concepts of narrative and plot are shattered to reflect the epistemological complexities of modernist fictionalization.

\section{Pessimism}

The modernist narratives express a sense of pessimism in their attitudes throughout the narration. They mostly focus on this strategy because of their break with the previous pretensions of optimism. The role of urbanization and world wars can not be ignored in this regard. Urban life and the impact of world wars made life complicated and hard to tackle. In this period, the writers flouted the conventional strategies of narrative and characterization to flaunt the disintegration of modern man. The role of alienation, which is the result of the isolation of man form a society in which lack of communication is widespread, can remarkably be observed in the pessimistic attitudes of modernists.

Another key term closely related to pessimism in modernist narrative is paranoia. "Paranoia, or the threat of total engulfment by some body else's system" is "keenly felt" by the modernist characters"'. (Lewis, 2001, p. 129). Here the skeptical paranoid characters who test truths and inquire into fundamentals, express their dissatisfaction, with life which does not work a certain way as against the Victorian narratives. The modernist characters are agonized by dread that someone is patterning you life, that there are all sort of invisible plots a foot to rob you of your autonomy of thought and action, that conditioning is ubiquitous.

The pessimistic modernist writers thought that the society was trying to Rob them of their "autonomy" and they had been conditioned by the traditional narrative techniques which had made them turn into anti- traditionalists. They believed in a general pessimism about the world, and rendered a rejection of society's certainties, a sense that only the artist is tells the truth. The reactions of modernist characterization in the development of this strategy can be fully elaborated in Bellow's work which will be discussed later on in the application section of the research under discussion.

\section{Irony}

Irony is defined as: "a statement in which the meaning that a speaker implies differs sharply from the meaning that is ostensibly expressed" (Abrams, 1971, p. 97). In modernist narratives, the role that irony plays can be quite remarkable because its function determines the way narration is distinguished from previous conventions. In modernist narrative, we no longer rely on "unity of mood" which orientates the readers' expectations, the "irony" of narratives makes the structures of modern narrations shattered and unpredictable so that the reader faces "juxtaposition" and not "simple narration" (Faulkner,1977, p. 16).

In modernist narratives irony is used for different purposes, but one of the eye-catching justifications behind this technique is the epistemological level of modernism. Matz has more to say on that as follows:

And worst, if truth recedes entirely, if there is a great difference between lost truths and bad realities, irony results. Irony- the bleak difference between what is and what ought to be, the wry gap between what is said on the surface and what is really meant - is often the end-point of the modern novel, where questioning and skepticism lead ultimately to the dismal discovery that things are very much not what they seem (2004, p. 34). 
In modernist narratives, "writers also test reality by showing how much it is "subjective'" (p. 23). Since the autonomy of the writers and their independence is revitalized only through the ironic distance they keep from the Victorian and realistic narratology. In realistic narratology, the events are naturalized and the readers are conditioned to follow the chronological or logical chain of events without taking the individuality of the characters into account, but modernist outlook toward narratology is uniquely constructed owing to its attentiveness to irony as the shelter from the past and "novels" which are "self-conscious about fiction's function" show "a new realism" directed at changing man's perception (p. 36).

Modernist narratives aim at flaunting realism ironically to show "aesthetic truth" (p. 77) as the alternative to the socially accepted realities. They usually pose some epistemological questions using ironic structures and the solution as opposed to realistic narratives turns ironically unexpected; consequently, a new form takes the place of traditionally accepted doctrines. They ironically break with the past to replace their subjective, epistemological creeds which are based on the internal world of the characters.

\section{POSTMODERNISM}

According to Lewis:

The strains of silence in literature, from Sade to Becket, convey complexities of language, culture, and consciousness as these contest themselves and one another. Such eerie music may yield an experience, an intuition, of postmodernism but no concept or definition of it (2001, p. 146)

Postmodernism is a comprehensive concept which has been challenged and argued over in so many scientific, literary, philosophical, cultural fields. Some critics regard it as originating in architecture. Based on natural attributes, it can not be defined as stable and fixed. Concerning the historical evidence of its formation, the following quotation may prove beneficial:

As for postmodernism, Arnold Toynbee detected its beginnings in the 1870s, Charles Olson and Irvin Howre, though they mean different things by it, saw it as emerging in the 1950s; Fredric Jameson, in one account,' in the late 1940s and early 1950s' in other around 'the end of the 1950s or 1960s' Charles Jencks's as beginning on 15 July 1972 at 3.32 p.m. for other post modernism is phenomenon of the eighties (Brooker, 1972, p. 4)

Hassan in Toward a Concept of Postmodernism thinks that a "period" is generally not a period at all; it is rather both a diachronic and synchronic construct". He further points out that postmodernism "requires both historical and theoretical definition" (1988, pp. 149-150). He further on says that no specific date can be determined for its beginning; also, he mentions the following relevant comments, "thus we continually discover 'antecedents' of postmodernism in Sterne, Sade, Blake, Lautréamont, Rimbaud, Jarry, Tzara, Hofmannsthal, Gertrude Stein, the later Joyce, the later Pound"'.(p. 150)

The above-mentioned quotation maintains the idea that postmodernism is not related to any specific period and as Hassan himself states, sometimes the "older authors are more postmodernist than younger authors" (ibid)

As was mentioned before, postmodernism is by nature indefinable; Nevertheless, critics have come up with different definitions about it. McHale believes that postmodernism, like Renaissance or Romanticism does not exist in the real world it is discursively made by readers and writers or literary historian; so as a discursive construct, we have:

John Barth's Postmodernism, the literature of replenishment; Charles Newman's Postmodernism, the literature of an inflationary economy; Jean-Francois Lyotard,s Postmodernism a general condition of knowledge in the contemporary informational regime; Ihab Hassan's Postmodernism, a stage on the road to the spiritual unification of Human kind; and so on.(1983, p.4)

Because of the mentioned qualities in postmodernism, critics such as Brain McHale and Linda Hutcheon emphasized a "poetics" for postmodernism. Hutcheon says that:

I see it as an on going cultural process or activity, and I think that what we need, more than a fixed and fixing definition, is a "poetics", an open, ever-changing theoretical structure by which to order both our cultural knowledge and our critical procedures.(1991, p.14)

Brooker in modernity postmodernism has come up with the following definition of postmodernism with the emphasis on its deconstructivity :

'Postmodernism' is too often associated with the merely stylistic features of self-conscious play and parody for it to serve the broader radicalizing purpose ascribed to it. In this mode postmodernism is generally explained as the result of psychic, technological and cultural worlds which have made any assumptions of a unified subjectivity and any reference to a 'real' rather constructed or simulated world impossible. (1972, p. 15)

As we can see here, some of the specific attributes of postmodernism in general have been brought up. The important point is that the disintegration of mind because of "psychic, technological and cultural worlds" cannot reflect reality as in realist and modernist modes and "reference" in postmodernism even to the created object is not possible. So nonreferentiality as Ihab Hassan, proposes, has been presented.

Here, the definition of Lyotard concerning postmodernism can help us in the pursuit of this trend and its characteristics. In the postmodern condition, he defines postmodernism as "incredulity toward metanarratives" (qtd. in Malpas, 2003: 24). "a metanarrative sets out the rules of narratives and language games " (p. 24). The postmodernist 
authors flout these metanarratives as ideologically constructed (Hutcheon, 1991, p. 104). So, postmodernism is "deconstructionist " (Hassan,1988, p. 151) by nature.

Postmodernism has some attributes similar to what we observe in deconstruction; They both target the metanarratives and demystify the ideological backgrounds behind the texts; But literary post modernist attitudes have "a desire to interrogate the nature of language, of narrative closure, of representation, and of the context and conditions of both production and reception" (p. 54).

The literary postmodernism lays bare "the process" of literary writing. The important point about postmodernism is that as "a contradictory phenomenon "it "uses and abuses, installs and then subverts, the very concepts it challenges" (Hutcheon, 1991, p. 3). Here, we encounter a big contradiction but it" is typical of postmodernist theory" because "the decentering of our categories of thought always relies on the centers it contests for its very definition". "There is no dialectic in the postmodern" (ibid) and the contradictions are paradoxically directed toward foregrounding metanarratives.

Postmodernism's contradictory nature leads us to another important concept put forward by Linda Hutcheon. "problematizing" postmodernism "raises questions about (or renders problematic) the common-sensical and the "natural" which appear in the form of metanarratives. It tries to problematize and make us question the norms, but it does not offer answers owing to its antitotalizing ideology". Offering answers is equal to making new "grand narratives which is against postmodernist poetics.

Back to postmodernist definition, Hawthorn in A Concise Glossary of Contemporary Literary Theory comes up with the following description to define the indefinable postmodernism:

Postmodernism, then, can be used today in a number of different way: (i) to refer to the non-realist and nontraditional literature and art which takes certain modernist characteristics to an extreme stage: and (ii) to refer to aspects of a more general human condition in the ' late capitalist' world of the post 1950s which have an all-embracing effect on life, culture, ideology and art, as well as some but not all usages to a generally welcoming, celebrative attitude towards these aspects.( 1992, p. 110)

Hassan in Toward a Concept of Postmodernism says that "postmodernism suffers from a certain semantic instability: That is, no clear consensus about its meaning exists among scholars" (1998, p. 149). This "semantic instability" has been one of the main reasons behind postmodernist similarity with deconstruction. Even, among critics and postmodernist philosopher, as was mentioned previously, no single description or theorization of postmodernism exists which more clearly proves the complexity and indefinability of the term. Later on, Hassan justifies the "semantic instability" of postmodernism as follows: (a)The relative youth, indeed brash adolescence. Of the term postmodernism and (b) its semantic kinship to more current terms equally unstable ...this can make for inspired debates.(p. 149)

So, as we notice the newness and association of postmodernism, with other trends such as modernism, "avantgardism" (ibid) and some literary movements which are simultaneously new, has complicated the maze of postmodernism as to its definition and theories.

Hutcheon in A Poetics of Postmodernism comes up with a very outstanding definition on postmodernism; She says that postmodernism is contradictorily dependent and independent from modernism and this characteristic as "typically contradictory" (1998, p. 18) to modernism shows the natural tendency of postmodernism because it is "perceived in terms of both continuity and discontinuity" to the previous trend (p. 149).

One of the characteristics of postmodernism is "the presence of the past" (Hutcheon, 1991, p. 20). Here, this quality can, as far as literary postmodernism is concerned, be ascribed to the natural tendency of postmodernism itself. Because of holding modernism as the past event and postmodernism as the present event, we can say it sticks to both past and present and the former title is present in the latter one. Postmodernism "doesn't deny the past" but "questions whether we can ever know that past other than through its textualized Remains" .It "literally names and constitutes its own paradoxical identity "by" (" an uneasy contradictory relationship of constant slippage" , (ibid)

One of the clearest definitions of postmodernism has been presented by Lyotard as proposing that:

The postmodern would be that which in the modern invokes the unpresentable in presentation itself, that Which refuses the consolation of correct forms, refuses the consensus of taste permitting a common experience of nostalgia for the impossible, and inquires into new presentations - not to take pleasure in them , but to better produce the feeling that is something unpresentable. (qtd. in Malpas, 2003, p. 49 )

Lyotard believes in the disruption of "established artistic structures" and "language games" by testifying to the existence of the unpresentable. By "unpresentable" he means not something which is missing from the "content of a work "but" a force that shatters ways of narrating or representing ". Postmodernism breaks "the rules" and regulations to which "viewers are used to and raises the ontological "question " of " what is art ?" or" what is really " in its structures (pp. 49-50)

Postmodernism is a phenomenon of vast interpretation and focuses on so many aspects. In different fields including literature, philosophy, social sciences, Arts, and so on what it tries to do is the portrait of all the artifacts as "Human constructs" (Hutcheon, 1988, p. 5) which are revised through its interpretive strategies as contradictory phenomenon in an interdisciplinary manner. The concept of originality in postmodernist literature will be discussed later.

Ontological Level 
Brain McHale in Postmodernist fiction puts forward the ontological dimension as the "dominant" of postmodernist fiction. This mode of problematization is concerned with "modes of being" and the kinds of questions raised by this technique are so various. Postmodernist fiction, according to McHale "deploys strategies which engage and foreground":

Questions like the ones Dick Higgins calls "postcognitive" "which world is this? What is to be done in it? Which of my selves is to do it? "Other typical postmodernist questions bear either on the ontology of the literary text itself or on the ontology of the world which it projects, for instance: what is a world? What kinds of worlds are there, how are they constituted and how do they differ? What happens when different kinds of world are placed in confrontation, or when boundaries between worlds are violated?; what is the mode of existence of a text, and what is the mode of existence of the world ( or worlds) it projects?; How is a projected world structured? And so on. (McHale, 1983, p. 10).

The philosophical preoccupations here do not rest at the level of epistemological knowledge as metanarratives: they problematize epistemological knowledge through "the mode of existence".

According to Brain McHale, the postmodernist writers come up with "a wide range of ontological attitudes or themes". The common ground of all these postmodernist writers is that they foreground the ontological concerns through "the same repertoire of strategies". McHale refers to an important point in the application of "ontology":

An ontology, writes Thomas Pavel, is" a theoretical description of a universe"... for the operative word in Pavel's definition, from my point of view, is the indefinite articled; an ontology is a description of a universe not of the universe; that is, it may describe any universe, potentially a plurality of universes. In other words, to "do" ontology in this perspective is not to seek some grounding for our universe; it might just as appropriately involve describing other universes, including "possible" or even "impossible" universes - not least of all the other universe or heterocosom, of fiction. (p. 27)

As we can see, Brain McHale does not believe in metanarratives or "grounding" for postmodernist ontology; so the worlds "in confrontation" do not come into any "dialects" (Hutcheon, 1988, p. x) ". For the real world to be reflected in the mirror of literary mimesis, the imitation must be distinguishable from the imitated" (McHale, 1983, p. 28).

One of the important reasons behind the ontological level of postmodernist fiction is that "the author as god" is shattered conceptually (29). This is mostly shown by comparing the world of the fiction to the real world in which "man's finite mind" can not understand the "unfathomable vast, ungraspingly complex universe. (p. 29).

Here, the artist who is faced with an "oppressive infinitude "(p. 30) is not able to act out the "author as god" (p. 29) anymore. The writer "makes his "(ironic) "freedom visible by thrusting himself into the foreground of his work (p. 30). Therefore, the writer "represents himself in the act of making his fictional world - or unmaking it "which ontologically foregrounds the narrative .consequently, we have the confrontation of different worlds layered upon one another. The important point to be made here can be quoted as, "The artist represented in the act of creation or destruction is himself inevitably a fiction. The real artist always occupies an ontological level superior to that of his projected" fictional self and doubly superior to the fictional world"' (p. 30)

Here, according to McHale, "there is a possibility of "infinite regress "which undermines the sense of originality and uniqueness of literary works to foreground the ontological dimension.

The above- mentioned quality leads us to another term which is crucial in the formation of ontological foregrounding -"short circuit" which refers to the writer who "penetrates his own fictional world" and he may introduce" himself to his characters" some times even the author explains the roles "to the characters" (p. 23) consequently the ontological level of the author as maker of the fictional world" confronts "the level of fictional world "and what is produced is something like a " short circuit " but the point to bear in mind is that, "as soon as the author writes himself into the text he fictionalizes himself, creating a fictional character bearing the name " Steve Katz" or "John Barth "... who is formally transworld - identical with himself', . (p. 215)

Here, I would elaborate on "psychological conceivability" according to which "a second world is accessible if it can be conceived by inhabitants of the first world" to achieve this aim, the postmodernists use "transworld identity":

If an entity in one world differs from its "prototype" in another world only in accidental properties, not in essentials, and if there is a one-to-one correspondence between the prototype and its otherworld variant, then the two entities can be considered identical even though they exist in distinct worlds (p. 35)

This parallelism between the two worlds makes the texts psychologically conceivable. But there are other aspects along with the similar features which foreground the ontological level because they are bizarre in the eyes of readers as producers of meaning.

\section{COMPARATIVE STUdY OF MODERNISM AND POSTMODERNISM}

Modernism and postmodernism have been critically analyzed by many critics. IHab Hassan, Brain McHale, Barry Lewis, Linda Hutcheon and other critics have some theorizations in this regard. The important philosophy behind their analyses is that they do not agree over the particulars, but the general notions are more or less similar; however no resolution is achieved as to the distinction between modernism and postmodernism. To elaborate more on the issue, I would cite Ihab Hassan's tabulation as quoted in Toward a Concept of Postmodernism (p. 152): 


\begin{tabular}{|l|l|}
\hline Modernism & Postmodernism \\
\hline Romanticism / Symbolism & Pataphysics / Dadaism \\
\hline Form (conjunctive, closed) & Antiform (disjunctive, open) \\
\hline Purpose & Play \\
\hline Design & Chance \\
\hline Hierarchy & Anarchy \\
\hline Mastery / Logos & Exhaustion / Silence \\
\hline Art object / Finished work & Process/performance / happening \\
\hline Distance & Participation \\
\hline Creation / Totalization & Decreation/ Deconstruction \\
\hline Synthesis & Antisynthesis \\
\hline Presence & Absence \\
\hline Centering & Dispersal \\
\hline Genre/ Boundary & Text/ Intertext \\
\hline Semantics & Rhetoric \\
\hline Paradigm & Syntagm \\
\hline Hypotaxis & Parataxis \\
\hline Metaphor & Metonomy \\
\hline Selection & Combination \\
\hline Root/ Depth & Rhizome/ surface \\
\hline Interpretation / Reading & AgainstInterpretation/Misreading \\
\hline Signified & Signifier \\
\hline Lisible ( Readerly) & Scriptible ( writerly) \\
\hline Narrative / Grand histoire & Anti-narrative/ Petit Histoire \\
\hline Master code & Idiolect \\
\hline Symptom & Desire \\
\hline Type & Mutant \\
\hline Genital / phallic & Polymorphous / Androgynous \\
\hline Paranoia & Schizophrenia \\
\hline Origin/ cause & Difference- Difference / Trace \\
\hline God the Father & The holy Ghost \\
\hline Metaphysics & Irony \\
\hline Determinacy & Indeterminacy \\
\hline Transcedence & Immanence \\
\hline
\end{tabular}

\section{HAMLET THE PLAY}

The leading characters of Shakespeare's Hamlet oscillate between two worlds of modernism and postmodernism. Hamlet's mysterious character displays an impressive sense of modernism. His ironic and pessimistic comments highlight this sense of impression.

On the other hand we can see Claudius and Gertrude breathing in the land of postmodernism by breaking the shackles of modern restrictions.

\section{A. The Epistemological Preoccupations of Hamlet}

Hamlet is constantly involved in a struggle with himself to see if he can find answers to the questions raised by his troubled life. In the following dialogue between Hamlet and his mother, Gertrude, some philosophical questions concerning "cynicism" are problematically raised to foreground the epistemological preoccupations of Hamlet as the protagonist of the play:

Queen: Good Hamlet, cast thy nighted colour off, and let thine eye look like a friend on Denmark. Do not fore ever with thy vailed lids seek for thy noble father in the dust. Thou know'st 'tis common. All that lives must die, passing through nature to eternity.

Hamlet: Ay, madam, it is common.

Queen: If it be, why seems it so particular with thee?

Hamlet: "Seems, madam? Nay, it is; I know not 'seems.' 'Tis not alone my inky cloak, good-mother, Nor customary suits of solemn black, Nor windy suspiration of forced breath, No, nor the fruitful river in the eye, Nor the dejected haviour of the visage, Together with all forms, moods, shows of grief/That can denote me truly. These indeed 'seem,' For they are actions that a man might play; But I have that within which passeth show-These but the trappings and the suits of woe."(Alexander, 1951, p.1031, henceforth Alexander).

Hamlet is warning us that we cannot rush to hasty judgment about what is going on in his soul, because this reality cannot be expressed in any outward mode or manner. He is making an epistemological point, about the radical inaccessibility of other mind. He is hinting that he senses a mystery in himself - a profound elusiveness that can only be expressed by the unspecific word "something." Hamlet is insisting on his own transcendence of the aspect he presents to the world - that he is more than he seems. This retort epistemologically points to the suspension and bewilderment that Hamlet's character as a paranoid identity ascribes to himself.

This epistemological questioning in the form of a soliloquy gives more credence to Hamlet's paranoid character as a modern man: 
O that this too too sullied flesh would melt, thaw and resolve itself into a dew, or that the Everlasting had not fix'd his canon 'gainst self-slaughter. O God! God! How weary, stale, flat, and unprofitable seem to me all the uses of this world! fie on't, ah fie, 'tis an unweeded garden that grows to seed; things rank and gross in nature Possess it merely. That it should come to this! But two months dead - nay, not so much, not two -So excellent a king, that was to this Hyperion to a satyr, so loving to my mother that he might not beteem the winds of heaven Visit her face too roughly. Heaven and earth, Must I remember? Why, she would hang on him As if increase of appetite had grown by what it fed on; and yet within a month -Let me not think on't - Frailty, thy name is woman -a little month, or ere those shoes were old With which she follow'd my poor father's body, Like Niobe, all tears -why, she -O God, a beast that wants discourse of reason would have mourn'd longer - married with my uncle, my father's brother - but no more like my father than I to Hercules. Within a month, ere yet the salt of most unrighteous tears had left the flushing in her galled eyes, She married - o most wicked speed! To post With such dexterity to incestuous sheets! It is not, nor it cannot come to good. But break my heart, for I must hold my tongue. (Alexander, p.1032)

In this soliloquy Hamlet's attachment to logocentrism as a modern man is vividly displayed, as he realizes that committing suicide would be considered a sin in the eyes of the "Everlasting" God who with his "canon 'gainst (self slaughter!)" would prevent him from reaching heaven.

Epistemological doubt as a dominant mode can be traced throughout the play; Hamlet is deprived of so many rights, encounters some mental, epistemologically posed questions which are typical of modern man.

The following monologue by Hamlet once again displays his logocentric attachment:

Now might I do it pat, now 'a is a-praying; and now I'll do't — and so 'a goes to heaven, and so am I reveng'd. That would be scanned: A villain kills my father; and for that, I, his sole son, do this same villain send to heaven.(Alexander, p. 1053)

\section{B. Stream of Consciousness}

This technique is mostly actualized in the form of interior monologue in this play. As was mentioned before, "the modernist writers use interior monologue to foreground their epistemological bewilderment"' (McHale, 1983: 8). As we go through the context, Hamlet's mental involvements are artistically displayed. His sense of confusion is mostly reflected in the way he describes the external objects according to his internal world as the decision-making touchstone in the formation of his personality. Hamlet's everlasting soliloquy proves the claim:

To be, or not to be - that is the question; whether; tis nobler in the mind to suffer the slings and arrows of outrageous fortune, or to take arms against a sea of troubles, and by opposing end them? To die, to sleep-no more; and by a sleep to say we end the heart-ache and the thousand natural shocks that flesh is heir to. 'Tis a consummation devoutly to be wish'd. to die, to sleep; to sleep, perchance to dream. Ay, there's the rub; for in that sleep of death what dreams may come, when we have shuffled off this mortal coil, must give us pause.......(Alexander, p.1047)

As we can see, the interior monologue reflects the way Hamlet considers the inner world as the basis for designing the external world and his subjective perspectives in his judgment on facial descriptions. In this play; the role of interior monologue is multi-faceted. If you take Hamlet into account, you will see how the interior monologues question his personality and the concept of his paranoid self.

\section{Pessimism}

A sense of strong pessimism can be traced in Shakespeare's Hamlet, which is a dominant trait of modernism. The following dialogue can be an apt example:

Queen: What have I done that thou dar'st wag thy tongue In noise so rude against me?

Hamlet: Such an act that blurs the grace and blush of modesty; calls virtue hypocrite; takes off the rose from the fair forehead of an innocent love, and sets a blister there; makes marriage-vows a false as dicers' oaths. O, such a deed as from the body of contraction plucks the very soul, and sweet religion makes a rhapsody of words. Heaven's face does glow o'er this solidity and compound mass with heated visage, as against the doom-is thought-sick at the act. (Alexander, p. 1054)

The above dialogue shows the paranoid attitudes, which maintain Hamlet's pessimism towards his mother and the whole surroundings as well. But Hamlet's interpretation of "truth" does not go beyond the epistemological limitations nor does it lead to schizophrenia in which delusions about reality dominate the characters.

The ironic look at pessimism and its epistemological bewildering aspect reaches a point where "abandoning the intractable problems of attaining to reliable knowledge of our world" is dominantly observed and narratives "improvise a possible world" (McHale, 1983, p. 10).

\section{Irony}

Throughout the play, ironic structures are evident. Hamlet uses his ironic rhetoric as tranquilizers. The following dialogue can support the claim:

King: My cousin Hamlet; and my son-

Hamlet: A little more than kin, and less than kind.

King: How is that the clouds still hang on you?

Hamlet: Not so, my lord; I am too much in the sun. 
Words are used as a double-edged weapon here, but a disguised weapon.

\section{E. Stream of Narration as a Technique in Hamlet}

Stream of narration is mainly concerned with narrative conventions. It defies linearity and foregrounds the ontological world of the text as producing different meanings and interpretations by the readers. It no longer admits the consciousness of the individual author as authentic, but through its discontinuous portrait of the narrative technique, helps the readers to produce a variety of meanings to denaturalizes "narrative continuity'. ( Hutcheon,1988, p. 13)

Shakespeare starts describing something, chooses a key point in that matter, elaborates on that key point so that the reader's mind is distracted, then he goes back to the issue at hand. This is vividly displayed in Claudius' public appearance after his hasty marriage to Gertrude:

though yet of Hamlet our dear brother's death the memory be green, and that it us befitted to bear our hearts in grief and our whole kingdom to be contracted in one brow of woe, yet so far hath discretion fought with nature that we with wisest sorrow think on him together with remembrance of ourselves. Therefore our sometime sister, now our queen, th' imperial jointress to this warlike state, have we-as 'twere with a defeated joy, with an auspicious and a dropping eye, with mirth in funeral and with dirge in marriage, in equal scale weighing delight and dole - taken to wife. Nor have we herein barred your better wisdoms, which have freely gone with this affair along. For all, our thanks. Now follows that you know. Young Fortinbras, holding a weak supposal of our worth or thinking by our late dear brother's death our state to be disjoint and out of frame, colleaguèd with the dream of his advantage, he hath not failed to pester us with message importing the surrender of those lands lost by his father, with all bonds of law, to our most valiant brother. So much for him. (Alexander, p. 1030)

In Hamlet, since the shift from modernism to postmodernism is quite tangible, so different layers of narration are juxtaposed, so that no single, linear, logical sequence of events can be traced. The reader is in a constant mood of suspense and uncertainty; some times, we may confront a sequentiality, but we are disillusioned as soon as the narrative itself is fragmented- such handling of narrative triggers the sense of undecidablity in Derridean terms and points to the fact that narrative itself is something arbitrary and pluralizes its interpretations in various situations based on the layer surfaced through the viewpoints of thoughtful readers.

Conventional dialogs reflect harmonious minds and intellectual stability among readers. In postmodernist, dialogues based on traditional norms are regarded as ideologically constructed and can not reflect the disordered and chaotic situation of man. In describing Hamlet's dilemma, only a shattered and disintegrated rhetoric can fully transfer the sense of anxiety and disturbance to the readers.

Stream of narration shows that narrative techniques are not natural phenomena behind all literary masterpieces. In addition, one of the important functions of stream of narration in Hamlet is that it defies a specific plot, setting and characterization.

\section{F. Fragmentation}

In Hamlet, fragmentation as a postmodernist technique is obtained through a kind of schizophrenic dissociation of the thoughts and observations. This can be felt in Gertrud's attitude towards Hamlet:

Queen: Good Hamlet, cast thy nighted colour off, and let thine eye look like a friend on Denmark. Do not fore ever with thy vailed lids seek for thy noble father in the dust.Thou know'st 'tis common. All that lives must die, passing through nature to eternity.(Alexander, p. 1031)

It can be also very appropriately felt in Gertrude's following question to Hamlet:

Queen: What have I done that thou dar'st wag thy tongue In noise so rude against me? (Alexander, p. 1054)

It seems as if Gertrud is not aware of her own hasty marriage after the mysterious death of her husband who loved her a lot. She even does not seem to ponder over the agony that her sole son Hamlet is undergoing. The whole thing shows Gertrud's fragmented mind.

\section{G. Logocentrism}

Logocentrism is a term coined by Derrida to denote the philosophies that are based on the idea that meaning is immediate and stable and that words and signs communicate directly and naturally. This idea has come under attack from both modern and postmodern theorists who conceive meaning as socially, culturally and historically mutable (Malpas, 2005, p. 135).

Derrida's focus on logocentrism is decentring religion which is the chaotic focal point in Shakespeare's Hamlet. According to the practiced Christian principles during the renaissance a man could not marry his brother's widow. Hence, Claudius' marriage to Gertrude is an anti-logocentric act.

\section{CONCLUSION}

In this paper, a number of modernist and postmodernist techniques were applied to Shakespeare's Hamlet to see how the shift from Modernism to Postmodernism can be accounted for in terms of contextual situations of the selected characters.

The use of irony in Hamlet makes us aware of what we regard as true and what the contextualized truth refers to; this 
quality arouses the sense of epistemological questioning in the readers.

Pessimism as actualized in the form of paranoia is prevalent in the Play. This technique mostly reflects the situation of Modern man as dismal and pathetic.

Pessimism can be the offspring of modernization and technological innovations. The important point to be made here is that in Hamlet all the above-mentioned techniques are simultaneously existent in a chain-like manner. They eventually point to the dominance of epistemology in this masterpiece. They interact together to problematize what the modern man is looking for as the final limit of knowledge.

Stream of narration which can be the counterpart of modernist stream of consciousness defies any narrative regulation and clearly puts the concept of narration into question. It points to the fact that narratives are ideologically constructed and as Hutcheon has repeatedly emphasized the norms and authority are shown to be arbitrary .Therefore, the concept of denaturalization is brought up in this regard .Consequently ,stream of consciousness as proposed by modernism can not be objectively rendered through ideological narratives.

Fragmentation reflects the anxious, schizophrenic situation of especially Gertrude in the play. It also reflects the way postmodernists regard life. They believe that mental fragmentation defies ideological narratives; even in modernism, individualism itself is made out of a dominant ideology which is deconstructively demystified through the postmodernist fragmented narratives.

The study has made an attempt to show the comparative and contrastive features of modernism and postmodernism, which co-exist in Shakespeare's everlasting tragedy.

\section{REFERENCES}

[1] Abrams, M.H. (1971). A Glossary of Literary Terms. $3^{\text {rd }}$ ed. New York and London: Halt, Renhart and Winston, Inc.

[2] Alexander, Peter. (1951). William Shakespeare: The Complete Works. London: Harper Collins Publishing.

[3] Bradbury, Malcolm, and James Mc Farlane, eds. (1991). Modernism: A Guide to European Literature. London and New York: Penguin Books.

[4] Brooker, Peter. (1972). Modernism/Postmodernism. London and New York: Longman.

[5] Cuddon, J.A. (1977). A Dictionary of Literary Terms. USA: Doubleday and Company, inc.

[6] Faulkner, Peter. (1977). Modernisms: The Critical Idiom. Ed. John D. Jump. London: Methuen and Co Ltd.

[7] Hassan, Ihab. (1988). "Toward a Concept of Postmodernism.” Postmodernism: A Reader. Ed.Thomas Docherty. New York: Harvester Wheatsheat.

[8] Hawthorn, Jeremy. (1992). A Concise Glossary of Contemporary Literary Theory. London and New York: Routledge, Chapman and Hall Inc.

[9] Huemer, Michael. (2005). Epistemology: Contemporary Readings. London and New York: Routledge.

[10] Hutcheon, Linda. (1991). Narcissistic Narrative: The Metafictional Pardox. London and New York: Routledge.

[11] Hutcheon, Linda (1988). A Poetics of Postmodernism. New York: Routledge.

[12] Levenson, Michael, ed. (2002). Modernism. Cambridge: Cambridge UP.

[13] Lewis, Barry. (2001). Postmodernism and Literature. The Routledge Companion to Postmodernism. Ed. Stuart Sim. London and New York: Routledge.

[14] macHale, Brian. (1983). Postmodernist Fiction. London: Routledge.

[15] Mlpas, Simon. (2003). Jean-Francois Lyotard. London: Routledge.

[16] Mlpas, Simon. (2005). The Postmodern: New Critical Idiom. London and New York: Routledge.

[17] Matz, Jesse. (2004). The Modern Novel: A short Introduction. Malden, Mass: Blackwell.

[18] Waugh, patricia. (1984). Metafiction: The Theory and Practice of Self-conscious Fiction. London: Routledge.

Noorbakhsh Hooti is currently an Assistant Professor of English Language and Literature at Kermanshah Razi University, Iran. $\mathrm{He}$ is a member of the research committee of the College of Humanities and Literature, Razi University. His main interests of research are drama, Short Story and Novel. He has been engaged in teaching English language and Literature for more than fifteen years. He holds Ph. D. in English Language and Literature, M. A. in English Language and Literature, and B.A in English Language and Literature. He has published a number of books, Research Projects, and articles in his areas of interest in academic journals. 